\title{
Rural Subsidizes and Revealing Moral Hazards
}

Balomenou Chrysanthi†, Maliari Marianthi, Semasis Simeon, Mamalis Spyridon, Pavlidis Stavros

EPOKA University, Tirana/Albania

International Hellenic University, Greece

\begin{tabular}{l}
\hline ARTICLE INFO \\
\hline Article History \\
\\
Received \\
Accepted \\
\hline JEL Classifications \\
Q14
\end{tabular}
ABSTRACT

\section{Purpose:}

At the end of the year 2013, the Greek Government to encourage the establishment of new enterprises in the agrifood sector announced the application of the program "New Farmers Installation within the financial framework of CAP". As a consequence, almost 8.000 young people benefited from this program as they received subsidizes up to $20.000 €$ to establish a new agro enterprise.

This work focuses on the examination of the results concerning those new entrants' enhancing of production of agro-products. Moral hazards have been created as some of them take advantage of the inefficacy of the program's control procedures and they contribute almost nothing to the final agro product.

Design/methodology/approach:

The paper is divided to into 2 parts. The literature of the theoretical perspective of the Greek economy is extensive. Taking under mind that Greece is a part of the European Union on the theoretical part are examined CAP's subsidizes consequences on Greek Agriculture. Then the "New farmers' installation" program is briefly presented. The theoretical part ends with references to moral hazards creation and corruption in Greece.

In the second part, the empirical results presented. The research took place during September 2016 using a formalized questionnaire. The statistical analysis included the estimation of frequencies, percentages, and means, as well as coefficient correlations.

\section{Finding:}

According to the findings, it has been supported that financial programs directed to agriculture should be monitored for disbursement. Otherwise, these programs cannot

Keywords:

Financial Marketing,

CAP,

New farmers,

Serres,

Greece achieve their targets such as the increase of in productivity in the agricultural sector. Moreover, the results of the study are similar to previous researches as Moral Hazards have been created.

Research limitations/implications:

Taking for granted that the lack of strict controls over the disbursement contributed to the increase in moral hazards, it is proposed that providing subsidies should be accompanied with disbursements only after strict controls. It is also suggested a combination as providing subsidies should only take place on the grants that the amount spent exclusively for rural enterprise liabilities

Originality/value:

This paper provides the impetus for the study of moral hazard on rural subsidizes and constitutes primary research

\section{Introduction}

After four decades, the implementation of the Common Agricultural Policy in Greece has not achieved its main goals. The production of agricultural products despite the huge amounts of subsidizes has been steadily decreased since 2007.

Moreover, at the same time, subsidizes on set-aside land have been increased. New CAP, with some improvements, aims to alter them to "farmers of the armchair". It is an under examination issue whether Greek agriculture failures. So, the implementation of a structural program in agriculture aims to increase productivity and the total production of agricultural products.

${ }^{\dagger}$ Corresponding Author: Balomenou Chrysanthi

Email: cbalomenou@epoka.edu.al 
This paper is divided into two parts, the first theoretical and second the empirical one and attempts to examine moral hazards creation on new farmers on R.U. Serres.

Serres, located in Central Macedonia-Greece close to the Bulgarian and F.Y.R.O.M. borders, can be characterized as a typical rural area. Serres is considered to be the poorest Greek Prefecture, so therefore, the consequences on Gross Domestic Product from the implementation of CAP in this area is are considered necessarily negligible. Also, it is worth noted that there are no sufficient controls and "farmers" take advantage of it.

The research examined the subsidies that "new entry" farmers received to establish an agriculture

Enterprise.

Nobel laureate authors as Stiglitz and Krugman have referred to CAP and its impact of on South European countries. Thus, there are many relevant references for European policies on agriculture. Additionally, data from the Hellenic Statistical Authority and other institutions have been analysed to depict crisis' reverberations on the one hand and CAP's consequences on the other, on agricultural production in Greece and particular on the local economy.

Furthermore, the above - mentioned authors analyzed moral hazards creation in other scientific fields, as the labor market and the banking system. Generally, moral hazards are more likely to occur where there are not sufficient controls. In a more general way and according to the recommendations of the reviewers in terms of the creation of Moral Hazards due to the lack of sufficient controls after the funding, we can enrich the current point, basing on the relevant literature, as follows, Edward T. Merkel (2009), Balomenou (2019):

- The Moral Hazard is revealing in Asymmetric Information and Financial Contracting. They result from the Adverse Selection, which is caused by asymmetric information before a transaction is consummated. More specifically, the Bank loan officer cannot easily distinguish the difference between high and low-quality borrowers. Part of the loan officer's job is to use credit analysis to uncover relevant information. Thus, Asymmetry of information is particularly acute for small firms since there is little publicly available information. As a result, loans are often structured so that borrowers can signal their true quality based on the types of loans they will accept. The arising question is whether the owner is willing to pledge personal outside assets as collateral or offer a personal guarantee? And if the owner is unwilling, this would signal that they are uncertain of the future.

- Under these conditions, the Moral Hazard occurs after the loan is made. Loan contract may give the firm the incentive to pursue actions that take advantage of the lender, subject of the bellow:

- If the firm does very well, the owner does not pay more to the issuer of the bank loan

- If the firm does poorly, the owner's liability is limited to the terms of the loan

Therefore, owners disproportionately share in the upside of increased risk, while lenders disproportionately share in the downside.

Finally, in many cases, there are common causes of revealing moral hazards creation.

Problems new entry farmers face as their rural enterprises are typical start- ups are also examined in this research. Porter (1998), and Pissaridis (cited on Piperopoulos 2007), have studied new and small enterprises problems.

Furthermore, in this research, it is examined innovating and traditional farms and their different trends on moral hazards creation.

In the second empirical part, empirical research was conducted by the means of a structured questionnaire. The questionnaire comprised of 156 items measured in 7 point Likert scale. Data selection was realized using a convenience and snowball sampling method during September 2016.

To participate in the research some criteria were used: the participant had to be a new entry farmer and received a subsidy for establishing their agricultural enterprise. In total, 156 valid questionnaires were gathered, a satisfactory sample size for the purposes of the research as well as the main statistical analysis utilized (Hair et al., 2010). Data analysis included descriptive statistics standard deviation, the coefficient of variation, coefficient of correlation and profile analysis. Data analysis included standard deviation of descriptive statistics, coefficient of variation, correlation coefficient, and profile analysis.

\section{Literature Review SUBSIDIZES IN GREEK AGRICULTURE 2.1 “Common” Agricultural Policy}

“The EU’s controversial Common Agricultural Policy accounts for 40 percent of the budget” (Stiglitz, 2016, pp372), and CAP is the only "common" remaining characteristic of the European Union. The fact that the recession in Greece returned to depression is -partly- a result of Greek agriculture's failure (Kirkylis \& Semasis, 2015). Increasing deficits in Greece on one hand -versus surplus in Germany, on the other hand, are part of European Trade Imbalances. Nobel nominated P. Krugman refers: "After the creation of the euro, the GIPSI economies (Greece, Ireland, Portugal, Spain, Italy) moved into huge deficits in their current accounts, a broad measure of the trade balance. Meanwhile, Germany moved into a huge matching surplus... That widening spread is at the heart of Europe's problems." (Krugman, 2012, pp91

As Greek agriculture is characterized by deficit, the volume of production has a strong impact on the Greek economy. Nobel awarded J. Stiglitz refers: "The way Europe chosen to get rid of trade deficits is to put the economy into depression"(Stiglitz, 2016, pp118). He also makes a comparison on of real cumulative CDP Growth in several European countries. He refers: "But looking within the eurozone, we see the pattern of divergence. While eurozone countries have not done well, some have grown modestly, while others like Greece have had calamitous declines". 
Analyzing exports "the 2010-2015 average growth rate for the volume of exports of goods and services: Cyprus, 1.75 percent; Greece, 1.18 percent; Ireland, 6.40 percent; Portugal, 4.68 percent; and Spain, 5.42 percent;” (Stiglitz, 2016 , pp.381). Even in comparison to the south-Europe countries, Greece has the worst performance. Thus, disparities in the EU have increased since the onset of the crisis. According to Stiglitz: “....enhanced divergence within Europe. The periphery countries became debtors with Germany as the great creditor”(Stiglitz, 2016, pp.119). European countries have not achieved economic or social convergence.

Additionally, according to Kyrkilis \& Semasis (2015), the decline of the Greek agriculture is not another outcome of the recent financial crisis but rather the continuation of a long trend starting right after Greece set the priority of industrialization in development strategy. Figure 1 depicts the Evolution of Agriculture Value Added (AVA) from 1970 .

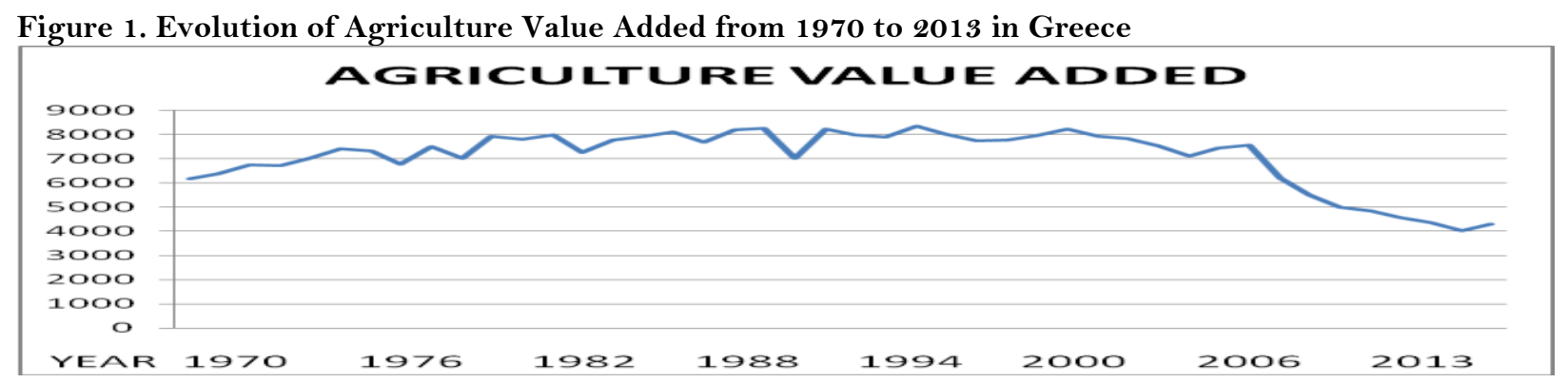

Source: Kyrkilis \& Semasis (2015)

Agriculture -GVA in Greece -and in region of Central Macedonia- had a sharp decline since 2006. Furthermore, according to the International Monetary Fund, Greece is the European Country with the largest output gap.

Apart from the crisis consequences, the reduction in agricultural production -due to CAP- is great since 2006. "It is worth referring to the fact that Gross Value Added at Agriculture has dramatically decreased since 2006. Until 2006, subsidies had been connected with agricultural production. Since 2006 each farmer has received a decoupled payment according to the production in previous years. From 2006 to 2013, Greek farmers received subsidizes due to their past production. As a consequence of the payment decoupling of Greek farmers reduced production volumes. Besides that, cultivated land has been reduced by the installation of photovoltaic systems on fields. (Balomenou \& Maliari \& Lagos, 2012, pp8)”. Figure 2 below present's data provided by the Hellenic Statistical Authority:

Figure 2: Agriculture-Gross Value Added

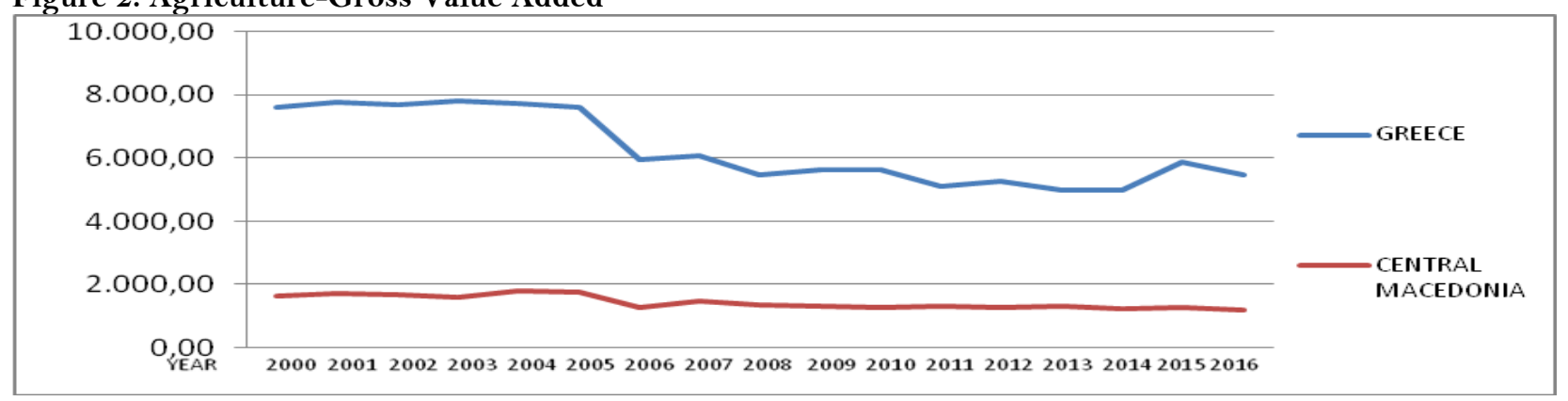

Source: Hellenic Statistical Authority

\subsection{New farmers' installation}

"In a purely agrarian economy, as more people leave, there is more land per worker, so incomes rise. This limits the extent of migration" (Stinglitz, 2016, pp.380). To reduce youth migration in Greece, and improve competitiveness the Ministry of Agriculture and Food under the framework of the Rural Development Program 2007-2013 "Alexandros Baltatzis", taking into account the specific needs of Greek farmers, announced on December 2013 the program "Measure 112-New Farmers Installation" (Governmental Papers 3254/B'/20.12.2013 \& 3255/B'/ 20.12.2013). The main targets were the following: a) to boost Greek agriculture competitiveness, b) to improve the environment c) to develop the country's rural areas. Up to 8000 new farmers benefited through financing support supplied by the European Agricultural Fund for Rural Development (EARFD). Table 1 presents the distribution of the budget per Greek region.

Table 1: New farmers' installation -Announcement December 2013- Distribution per Region 


\begin{tabular}{|c|c|}
\hline GREEK REGIONS & $\begin{array}{c}\text { Amount of Subsidizes } \\
\text { (in Euros) }\end{array}$ \\
\hline EAST MACEDONIA \& THRACE & 12.600 .000 \\
\hline CENTRAL MACEDONIA & 32.400 .000 \\
\hline WEST MACEDONIA & 6.300 .000 \\
\hline EPIRUS & 5.100 .000 \\
\hline STEREA GREECE & 5.900 .000 \\
\hline THESSALY & 13.600 .000 \\
\hline IONIAN ISLANDS & 1.400 .000 \\
\hline PELOPONNESE & 14.700 .000 \\
\hline WEST GREECE & 15.500 .000 \\
\hline NORTH AEGEAN & 7.400 .000 \\
\hline SOUTH AEGEAN & 1.600 .000 \\
\hline CRETE & 22.800 .000 \\
\hline ATTICA & 700.000 \\
\hline TOTAL & $\mathbf{1 4 0 . 0 0 0 . 0 0 0}$ \\
\hline
\end{tabular}

Source: Ministry of Agriculture and Food

Each new farmer has received a minimum of 10.000 up to a maximum of $20.000 €$. The amount of credit was estimated as it is depicted in table 2 .

Table 2: New farmers' installation -Criteria

\begin{tabular}{|c|c|c|}
\hline Criterion & & Amount of subsidizes \\
\hline Permanent residence & Mountainous & 7.500 \\
\hline & Semi-mountainous & 5.000 \\
\hline & Lowland areas & 2.500 \\
\hline Kind of production & Livestock & 7.500 \\
\hline & Plant production & 7.500 \\
\hline & Livestock \& plant production & 5.000 \\
\hline Future income & $>120 \%$ standard income & 5.000 \\
\hline & $80 \%-120 \%$ standard income & 2.500 \\
\hline
\end{tabular}

Source: Ministry of Agriculture and Food

Mind that $70 \%$ of the above mentioned amount was distributed on in December 2014, it is figured that there were distributed about 12000 Euros per new farmer. The rest amount has not been distributed to all new farmers until now (January 2019).

New farmers' enterprises are start-ups. Thus, they face all problems start-ups face. Porter refers: "As a result of newness, the high level of uncertainty, customer confusion, and erratic quality, the emerging industry's image and credibility with the financial community may be poor" (Porter (1998) pp. 223).

Stiglitz adds that especially in Greece and other crisis countries new entrepreneurs face even more obstacles. As new farmers are micro enterprises (Nobel nominated) Pissaridis (cited in Piperopoulos (2007) noticed "in every type of economy, smaller enterprises are punished by facing higher interest rates than bigger enterprises”, Stiglitz recently added: "Important credit channels, especially to small and medium-size business were clogged" (Stiglitz 2016, pp. 170) and "Decreased availability of loans to small and medium size enterprises further diminishes opportunity on the crisis and near-crisis countries, encouraging even more migration” (Stiglitz (2016, pp 135).

It is worth noting that the first disbursement of this particular program - $60 \%$ of the total budget - have been received by the farmers without any control.

The rest $40 \%$ is given gradually after strict controls. It should be noted that $60 \%$ of the above-mentioned amount has been distributed in December 2014-, a few days before Greek national elections, whereas the allocation of the balance (et. $40 \%$ ) is pending till now. The under examination issue refers only to the first disbursement (December 2014).

\subsection{Moral Hazards revealing and corruption}

Moral hazards arising in other scientific fields have been thoroughly studying since the early nineteen's. Patrick Rey and Joseph E. Stiglitz, "Moral Hazard and Unemployment in Competitive Equilibrium," 1993 working paper was the basis of Nobel Prize that was awarded to J. Stiglitz (Stiglitz, 2016, pp.382).

From its nature, the Greek macro and microeconomic environment are affected by the political clout. In such an environment corruption rises. Indicatively we are presenting a relevant part of Stiglitz's recent work as Stinglitz (2016) refers "obviously, corruption can make matters worse, with a corrupt financial sector paying kickbacks in one form or another to corrupt politicians or their political parties”. (Stinglitz, 2016, pp.112). 
Since the main characteristic of New farmers installation Program" is the lack of controls on the first disbursement, the current research examined whether "new farmers" produced or not agricultural products or they have just received subsidizes taking advantage of the fact that no strict controls are foreseen under this framework.

It should be noted that in similar programs implementing in other European countries legally are not imposed controls before the first disbursement. However, due to specific structural malfunctions of the Greek economy, specific controls regarding all the phases of the assessment (ex-ante, ongoing and ex-post) should be foreseen. Coming to an end, the efficient ethical performance of the "New farmers installation Program" is questioning.

\section{Data, Methodology and Empirical Results- RESEARCH ON LOCAL NEW FARMERS}

\subsection{Data}

We addressed only to those farmers who received the new farmers' installation subsidize. The participants in the research were 156 new farmers from 702 who benefited from this program in the Regional Unity of Serres. The question-based research was conducted in September 2016, almost two years after new farmers' entrance. All participants were between 18 to 40 years old. The population of the research was the beneficiaries of the Measure 112New Farmers Installation. The sampling method followed in this research was convenient sampling

\subsection{Methodology implementation- Descriptive statistics and correlations}

The results of the research have been analysed using the SPSS statistical program. Descriptive statistics have been employed to calculate the main statistical measures, average, standard deviation, coefficient of variation and coefficient of correlation. It is worth noting that our empirical research was conducted three years after the announcement of the program.

\subsection{Empirical Results}

The main question in this research is whether or not new farmers produce agricultural products, cultivate their land and sell their products or not. This question separates producers from those who just receive subsidizes In figure 3 bellow, we present the percentage of new farmers that proves they have cultivated and sold their products.

Figure 3: Present the percentage of producers

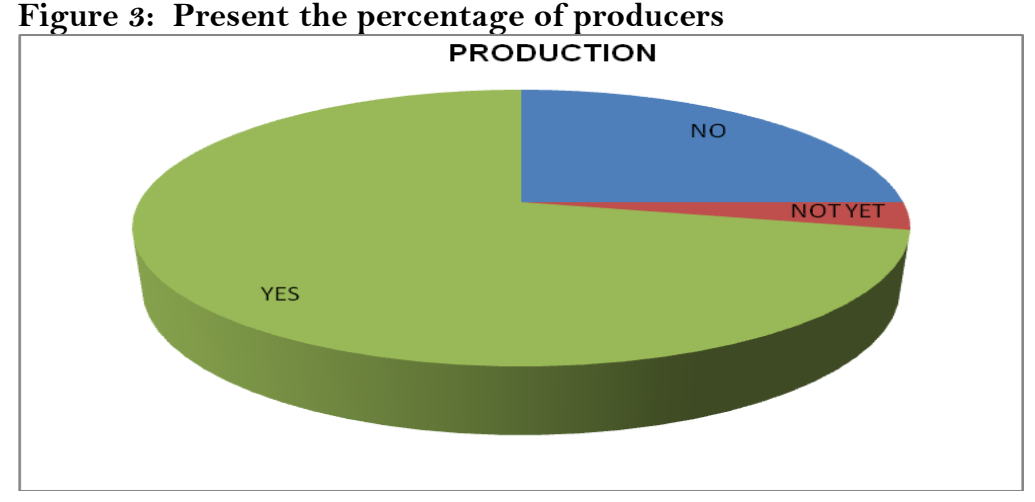

The majority $(75 \%)$ of participants have decided to work in fields. Five new farmers have not yet sold their products as they have planted Cherrie trees and vineyards. These participants have been included in the research results, as producers.

Nowadays "Competition based on innovation is characterized as strong competition. On the other hand, Competition based on low cost policy is characterized as weak competition” (Observatory of European SMS's, 2007).

In table 8 below is presented the percentage of innovative crops compared to traditional. The greatest biggest problem in Greece, during this depression, is the lack of innovation plans. The great importance of innovating projects and plans in Greece has almost completely been neglected even in recent years. According to Piperopoulos (2007) "Greek's financial strategic appears to have no connection to innovating plans." Statistical data for the years 2000-2005 presented that Greece failed from the 14th position in competitiveness in Europe ( 15 countries) to the $23 \mathrm{rd}$ position (25 countries). It has been predicted that Greece would probably be at the same level of innovation with other European countries in 40 years.

In addition, Mr. Christos Meglas, president of Serres Chamber of Commerce said that "Nowadays our products due to the elimination of distances may possibly approach to markets that are situated far away even to the remotest areas at a low cost. This is globalization in real terms and that we need to do is to fight for and innovate so as to survive in the future."

In the present research, innovating crops have been defined crops such as aroni, mushrooms truffle, oregano, walnuts, lentils, sesame, peanuts, organic trefoil and organic vegetables. Since it has been recognized that organic farming in 
Greece is still, unfortunately, in the embryonic stage of development, Greek organic farm enterprises can be considered as innovative ones as they produce differentiated products.

Figure 4: Innovative agriculture

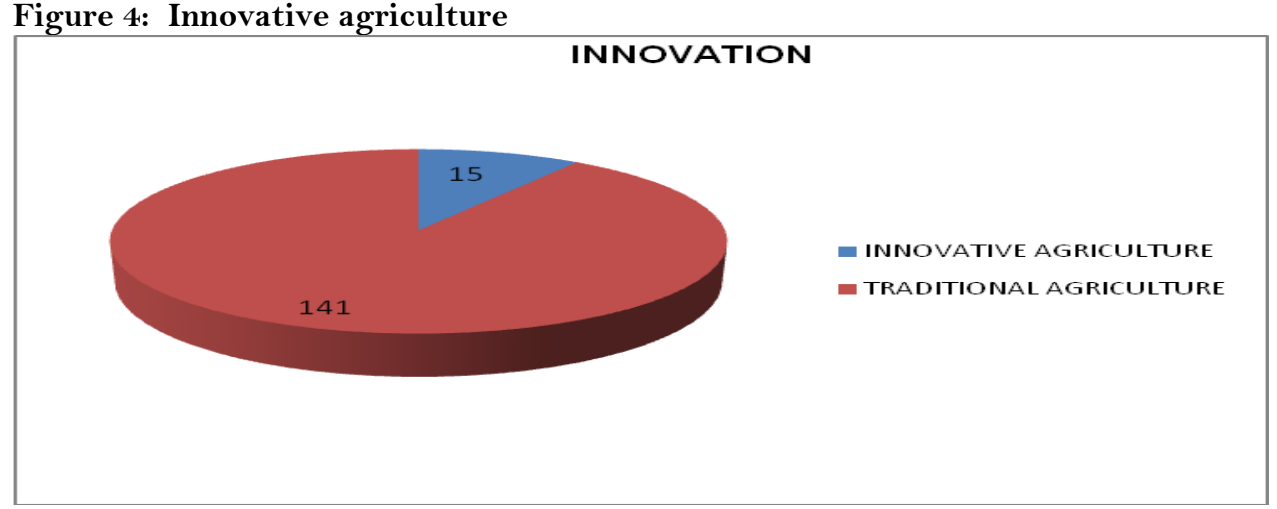

On the following tables $5 \& 6$ it is presented the differentiated approach towards production between innovative and traditional farmers.

Figure 5: Production of innovative and traditional farmers

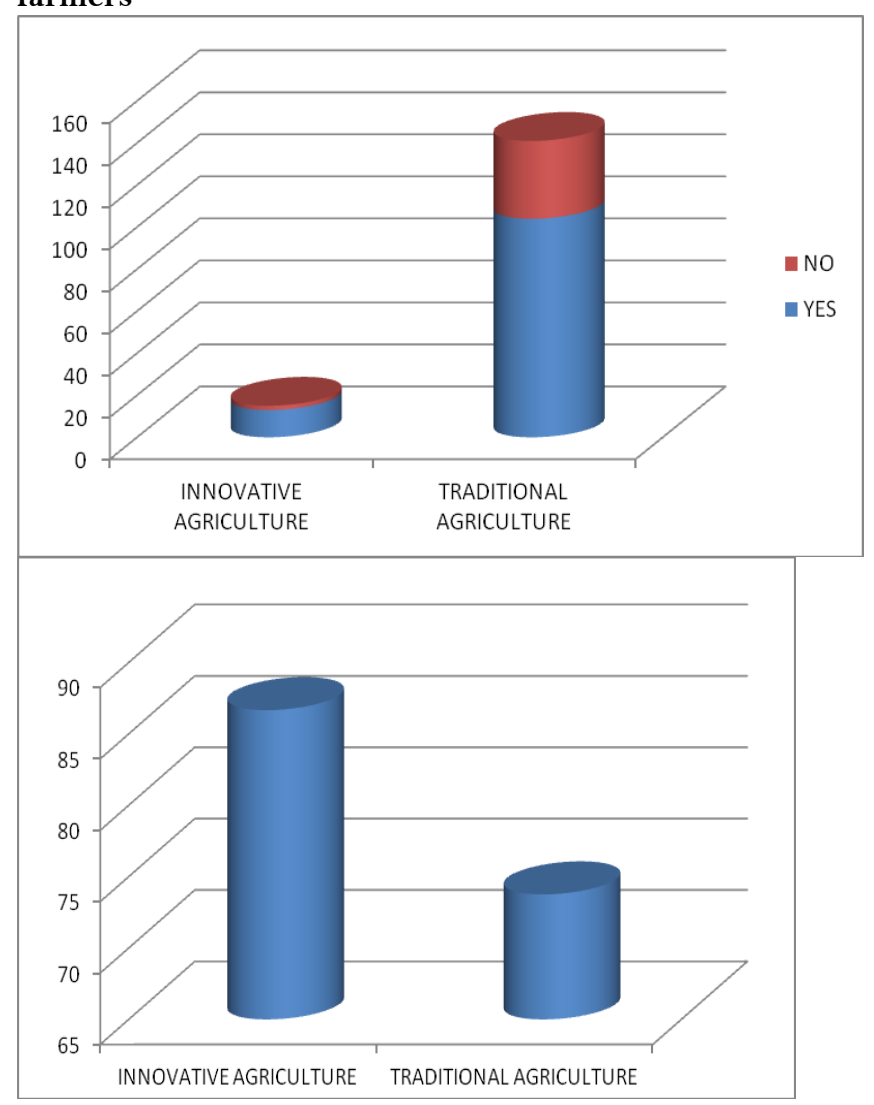

Figure 6: Percentage of Production of innovative and traditional farmers

According to the results - above graphs - innovative farms produce more (85\%) whereas traditional agricultural farms production is $71 \%$; the vast majority of farmers that have been defined as innovative are producers. In contrast, almost a quarter of the farmers that have been defined as traditional do not produce at all. Table 7 presents the production sectors of the New Farmers participants. Results showed that only a small proportion of them are stockbreeders while the vast majority cultivate plants and trees. 
Figure 7: Farmers with crops/ livestock breeders/both crops and livestock

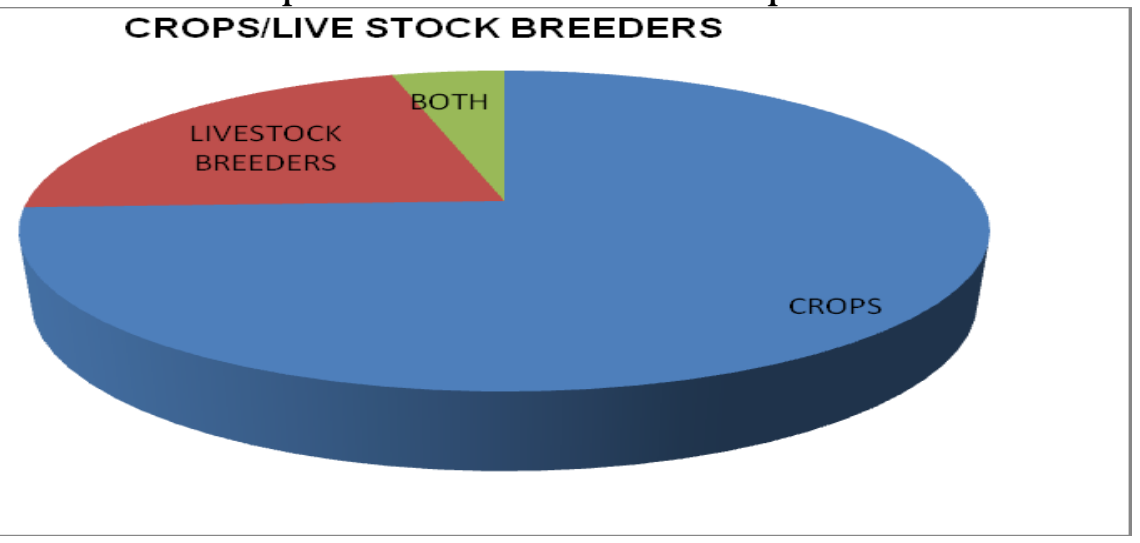

In the following tables $8 \& 9$, it is presented the differentiated approach towards production between farmers with crops, livestock breeders and farmers with both crops and livestock and their percentage. Livestock breeders have near zero possibilities to create moral hazards as they all produce milk or meat.

Figure 8: Production of farmers with crops/ livestock breeders/both crops and livestock

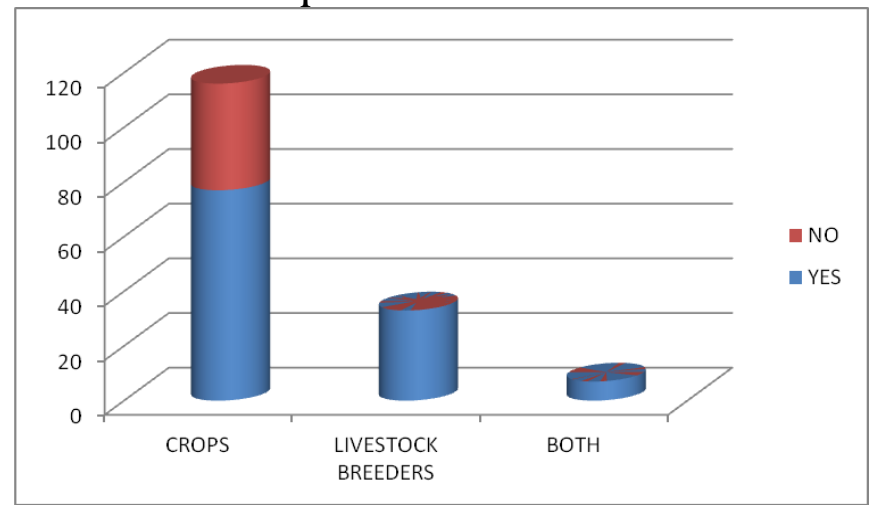

Figure 9: Percentage of farmers with crops/ livestock breeders/both crops and livestock

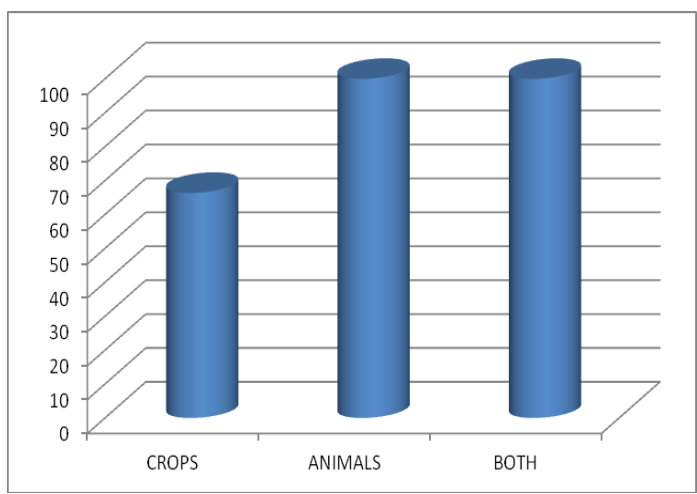

Taking as a granted that livestock breeders have near zero possibilities to create moral hazards, on in the table 10 below it is presented farmers' distribution according to their size. The majority of new farmers' arable land is just 1-5 acres.

Figure 10: Farmers distribution according to rural enterprise's size

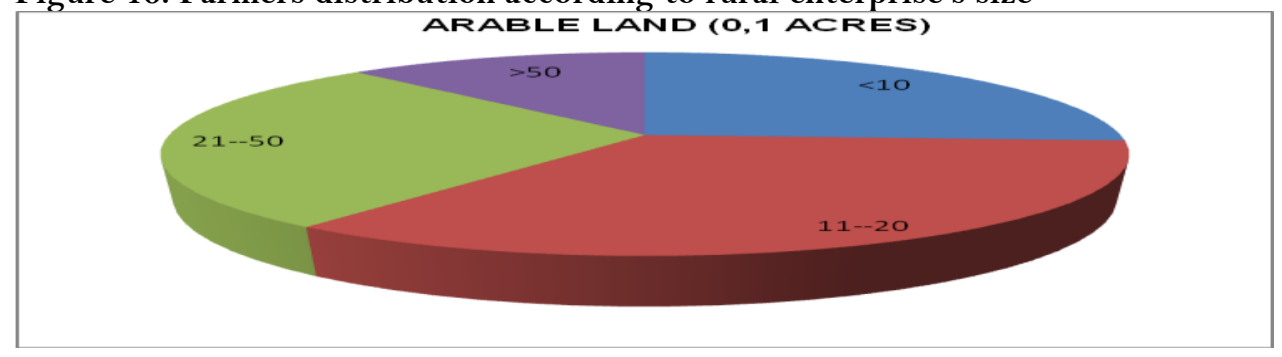

In the following tables $11 \& 12$, it is presented the multiple approaches approach towards production according to rural enterprise's size.

Figure 11: Production of farmers according to rural enterprise's size (in 0,1 acres)
Figure 12: Percentage of farmers according to rural enterprise's size (in 0,1 acres) 

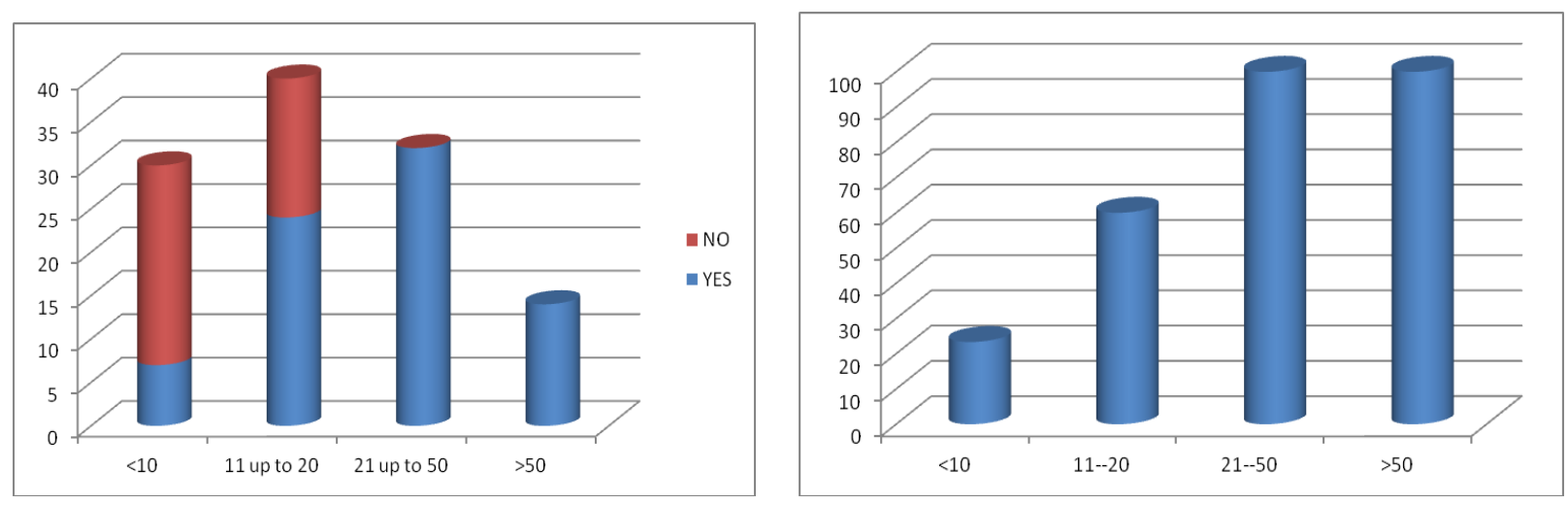

Moral hazards' creation depends on the enterprise's size. Large farms appear fewer possibilities to create moral hazards. According to previous researches on enterprises activated on the industry, commerce, and services (Balomenou, Maliari, Semasis 2017) "firms at the average size lurks the greater moral hazards". Consequently, moral hazards are unlikely to be created in large farms. On the contrary, less than $30 \%$ of small farmers who cultivate less than 1 hectare can prove that they produce and sell agricultural products. These young people decided to receive subsidiaries up to $20.000 €$. They did not invest on equipment and the majority "cultivate" vegetables such as green beans or spinach, because the main condition to receive subsidiaries is to "cultivate" 0,7 acres of vegetables. In general, after interviewing them, they declare that they will abandon agriculture five years later when the program New farmers Installation will be completed. Thus they have the greatest possibilities to create moral hazards.

Table 13 below presents new farmers' sex. The vast majority (67,98\%) of the new farmers are men.

Figure 13: Farmers distribution according to new farmers' sex

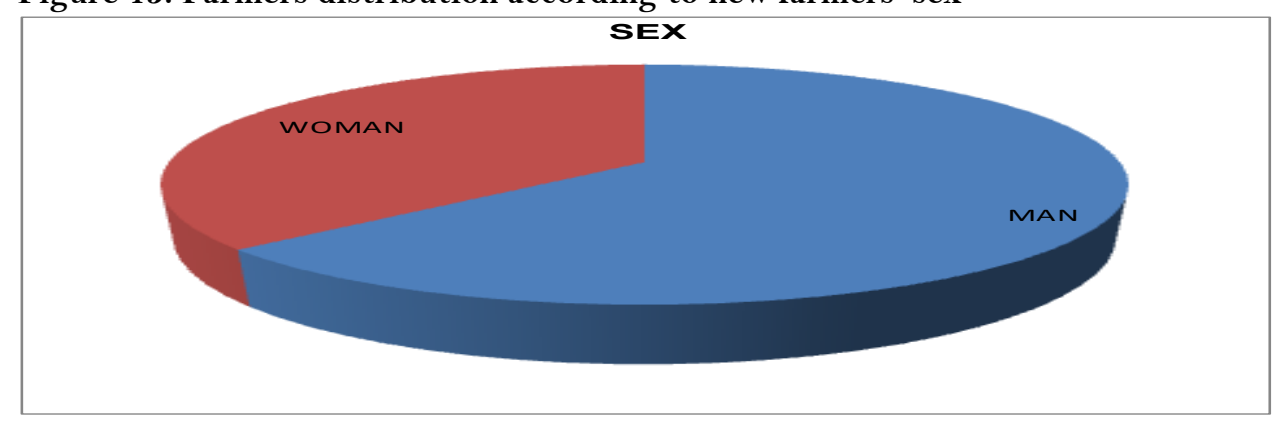

In the following tables $14 \& 15$, it is presented the differentiated approach towards production according to new farmers' sex.

Figure 14: Production of farmers according to new farmers' sex
Figure 15: Percentage of farmers according to new farmers' sex 


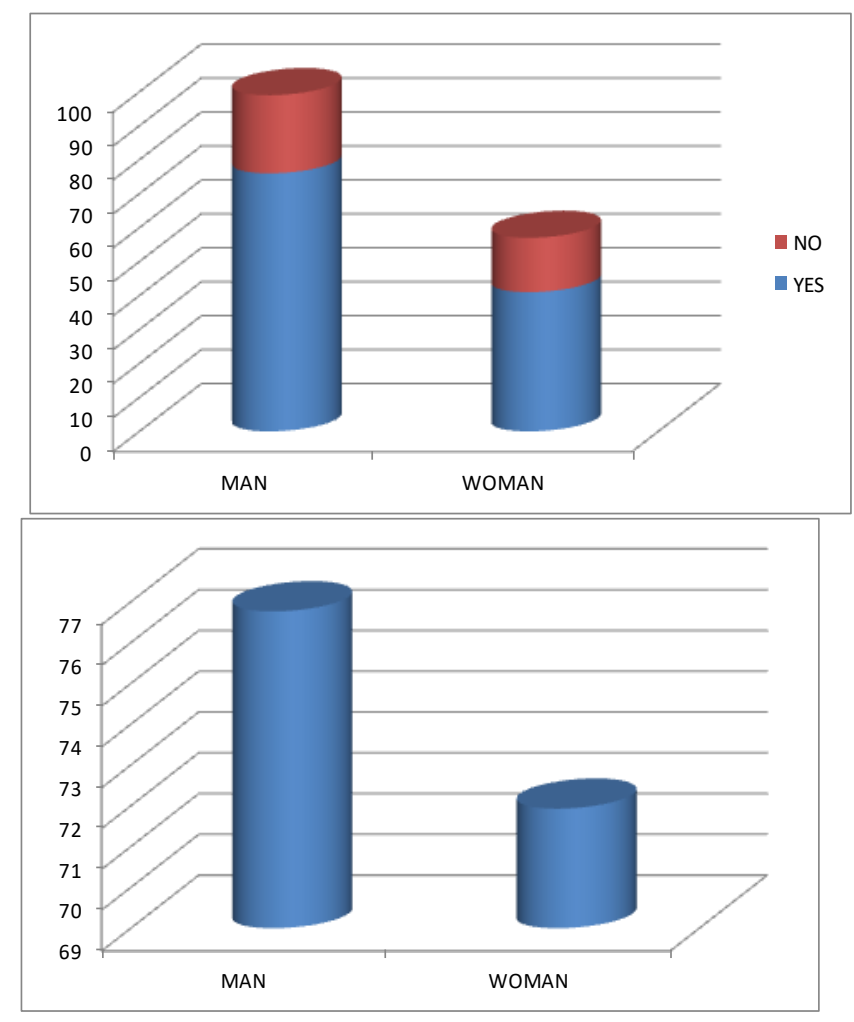

Moral hazards' creation is differentiated in two sexes. Men have greater possibilities to produce and sell agricultural products than women, so it is more likely moral hazards to be created by women.

In table 16 below, it is presented the farmers' distribution according to new farmers' former employment status.

Figure 16: Farmers distribution according to new farmer's former employment

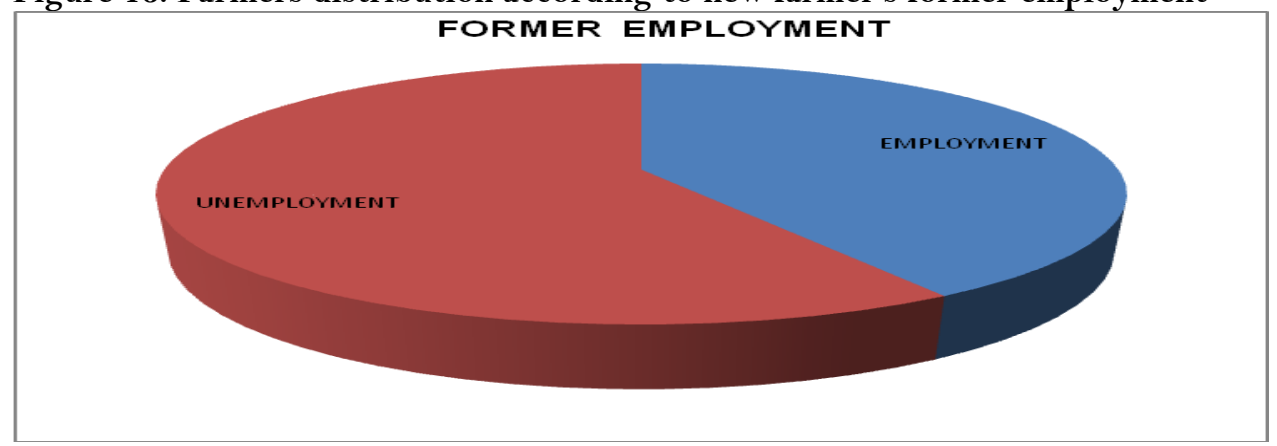

The following tables $17 \& 18$ present the former employment status of new entrants in agriculture. The majority of new farmers were previously unemployed. So the EU programme was a great opportunity for them to start up a new enterprise in the agricultural sector.

Figure 17: Production of farmers according to new former farmer's employment
Figure 18: Percentage of farmers according to new farmers' former employment 

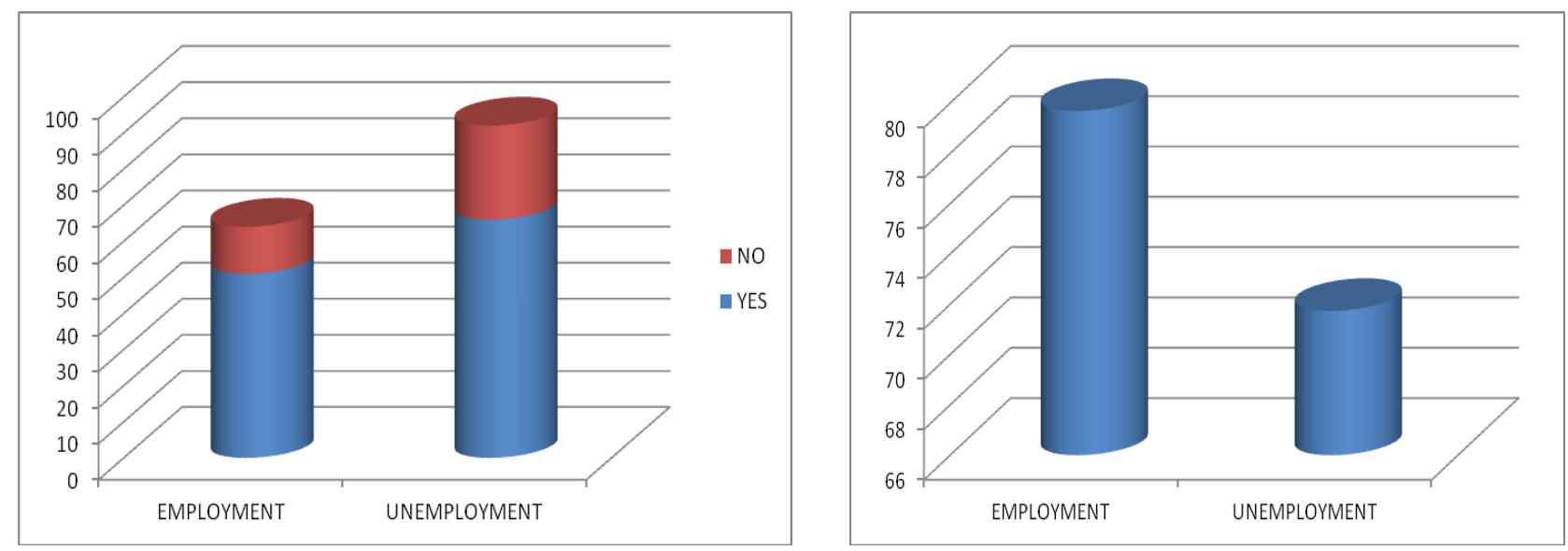

The percentage of those who will be just subsidiary seekers in the future is lower in this category compared to those who were occupied in different a sector in the Economy.

Table 19 presents the level of education; the majority of the new farmers have accomplished high school or technical school (13 years in education)

Table/Figure 19: Farmers distribution according to new farmer's education

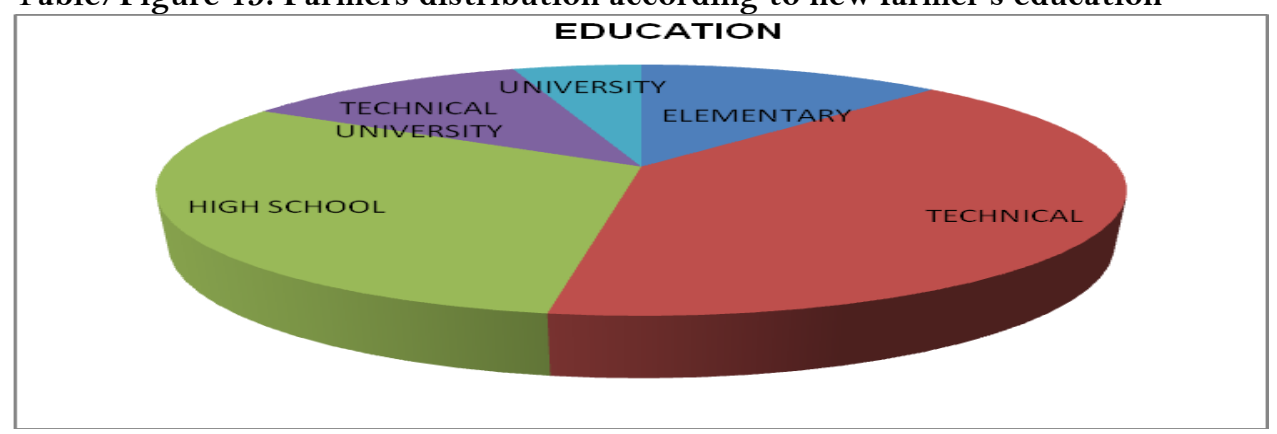

In the following tables $20 \& 21$, it is presented the differentiated approach towards production according to the new farmers' education.

Figure 20: Production of farmers according to new farmers' education

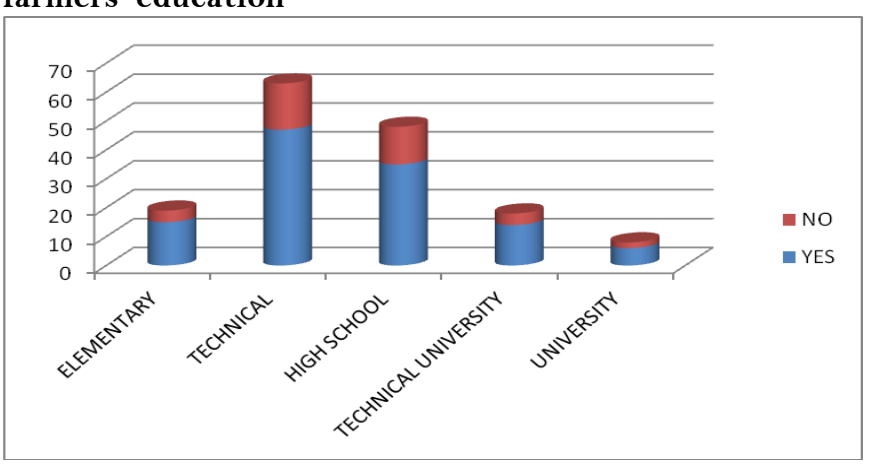

Figure 21: Percentage of farmers according to new farmers' education

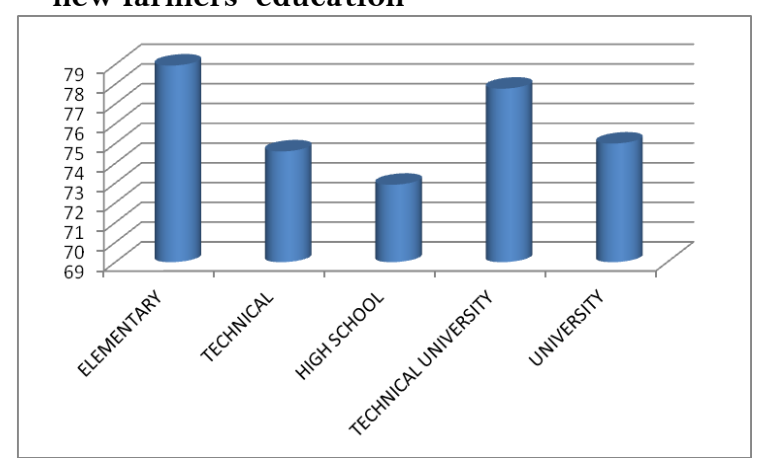

It is obvious that high school graduates produce less, while those who did not finish high school in their vast majority are employed in the primary sector ( $79 \%$ of them produce). Taking under consideration that there are no substantial differences between graduates, moral hazards are more likely to be created by high school graduates $(73 \%$ of them produce). In parallel, research had examined whether there are any differences regarding the performance of bachelor degree holders. The results have shown that university graduates especially from other scientific fields than the primary sector have more possibilities to create moral hazards.

One of the main perquisites of this program was the new farmers' age to be from 18 up to 40 years old.

So it should be noted here that our empirical research was conducted three years after the announcement of the program. In table 22 below, it is presented farmers' distribution according to new farmers' age. 


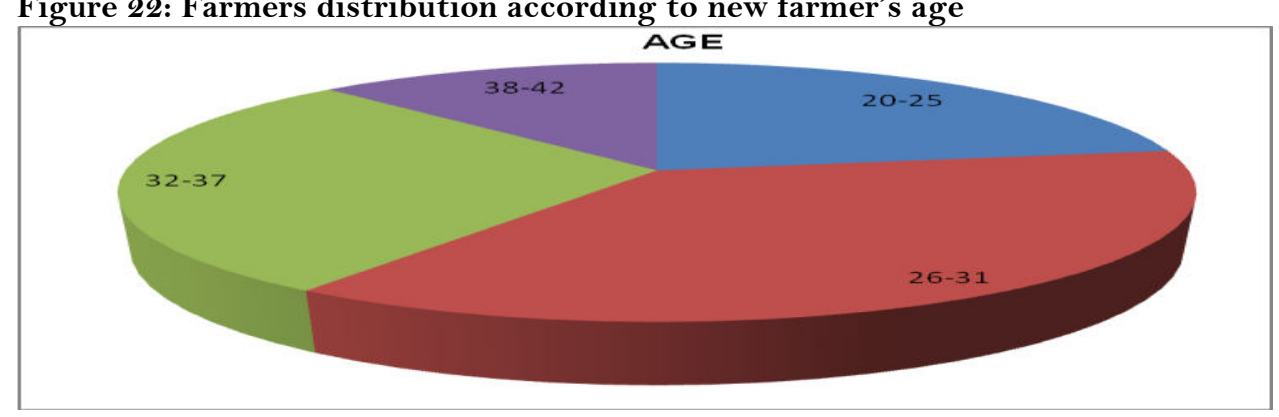

In the following tables $23 \& 24$, it is presented the differentiated approach towards production according to new farmers' age during the application period.

Figure 23: Production of farmers according to new farmers' age

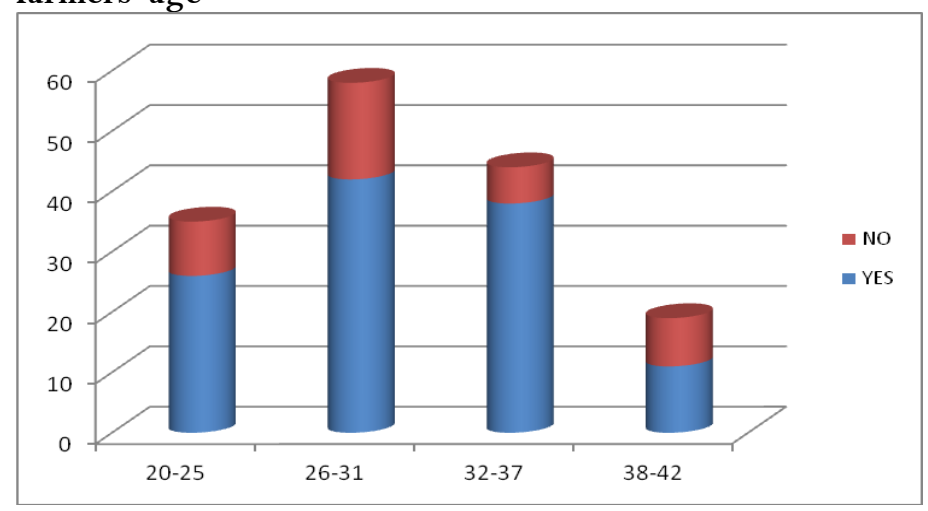

Figure 24: Percentage of farmers according to new farmers' age

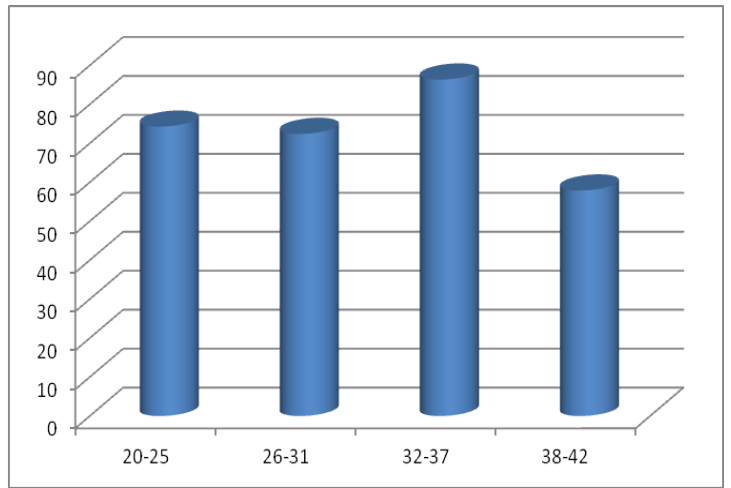

Those who approach 40 years old have the most possibilities to create moral hazards as, according to our findings, they produce less.

\section{Conclusion}

Almost four decades after Greece become a member of European Communities, Greek agriculture faces many challenges. The main one for the agricultural sector is to use subsidies in order to increase the competitiveness of the agricultural sector. Therefore, financial support from the CAP should be achieve its optimum goals. Policy makers should take into consideration in the planning of this support the possible moral hazards that can be created due to mistakes in policy planning. The present research revealed such moral hazards in development programs.

In recent years the resources of the CAP have not been used properly. Total productivity has been decreased since 1981 despite the development programs and the subsidies that the Greek farmers have received.

Especially for Serres a typical rural area and simultaneously the poorest Greek Regional Unity, the decrease in Gross Value Added raises questions about the of role of CAP.

The main result of the current research is that the provision of subsidies without strict controls (ex-ante, ongoing and ex-post) on disbursements enhances the revealing moral hazards. Apart from their differences many new farmers choose to benefit from subsidies and do not produce at all.

However it should be noticed that the probability of potential moral hazards is not referred to livestock breeders. On the other hand, those who cultivate a few acres of arable land it is very likely to perform potential moral hazards while rural enterprise's size affects farmers' behavior.

Finally.it still remains as the main goal a comparison analysis between CAP -Measure 112/2013-2014 and CAP Measure 6.1/2016-2017

\section{References}

Balomenou C., 2003,The Greek Banking System and the Procedures of Evaluating Investment Plants. Papazisi, Athens Balomenou. C., Maliari M. \& Semasis S. (2017) DEPRESSION IN GREECE AND REVEALING MORAL HAZARDS ON ENTREPRENEURSHIP FINANCIAL GUARANTEES. Journal of Business Paradigms, http://journal.par.hr/archives/send/6-vol-2-no-2/27-depression-in-greece-and-revealing-moral-hazards-on-entrepreneurshipfinancial-guarantees 
Balomenou. C., Maliari M. (2011) Consequences of Financial Crisis on Loan Providing Funds for Small \& Medium Enterprises: Former Prefecture of Serres-Greece, In: Special Session ZZQ SS: The impact of Global Financial Crisis on the Banking Sector, in local - national -international Level, 201, ERSA Congress, Barcelona, Spain.

Balomenou. C., Maliari M. And Lagos. D. Interaction between bank branches, local entrepreneurship and development on rural and suburban areas -Regional Unity of Serres https://www.econstor.eu/bitstream/10419/120694/1/ERSA2012_0801.pdf

Hair J. et al. ,2010, Multivariate Data Analysis Pearson, New International Edition, Edinburgh

Hellenic Statistical Authority (2017), available at: http:// www.statistics.gr \& http://dlib.statistics.gr/portal/ page/portal/ $\mathrm{ESYE} /($ December 2017).

Krugman, P., 2012, End this Depression now, W.W. Norton \& Company, New York-London

Kyrkilis D. \& Semasis S. (2015) Greek Agriculture's Failure. The Other Face of a Failed Industrialization. From Accession to EU to the Debt Crisis. Procedia Economics and Finance. Volume 33, 2015, Pages 64-77

Ministry of Agriculture and food (2017) available at: http://www.minagric.gr/(December 2017).

Observatory of European SMS's (2017) available at: http://ec.europa.eu/growth/smes/business-friendlyenvironment/performance-review-2016_en \& http://eomag.eu/articles/572/the-observatory-of-european-smes (November 2007).

Piperopoulos, P. ,2007, Entrepreneurship, Innovation \& Business Clusters. Macedonian University Publishes, Thessaloniki

Porter M., 1998), Competitive Strategy-Techniques for analyzing industries and Competitors. The Free Press, New York

Rural Development program in Greece 2007-2013 (2017) available at: http://www.agrotikianaptixi.gr/index.php?obj=9d5d8678aa9e1d7c (accessed 13 December 2017) \& http://www.agrotikianaptixi.gr/index.php?obj=4c1776c316a3cccb (December 2017).

Rontos, K. and Papanis E., 2007,, Statistical research, Sideri, Athens

Serres Chamber of Commerce and Industry, (2018) available at:

http://www.serreschamber.gr (January 2018 ) \&

http://www.eves.gr (January 2018)

Stinglitz J., 2016, The euro-How a common currency threatens the future of Europe, W.W.Norton \& Company Inc. New York

This is an Open Access article distributed under the terms of the Creative Commons Attribution Licence

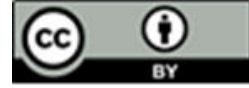

